\title{
PReS-FINAL-2141: Clinical features, therapeutic interventions and outcome of 362 patients with macrophage activation syndrome enrolled in a multinational survey
}

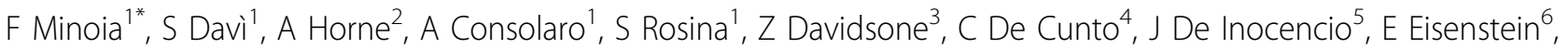

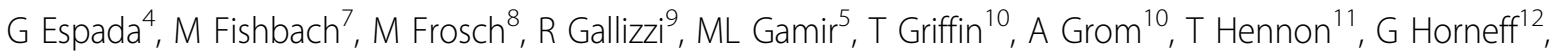 \\ Z Huasong $^{13}$, N Ruperto $^{1}$, A Martini ${ }^{1}$, RQ Cron ${ }^{14}$, A Ravelli $^{1}$
}

From 20th Pediatric Rheumatology European Society (PReS) Congress Ljubljana, Slovenia. 25-29 September 2013

\section{Introduction}

A multinational collaborative effort aimed to develop a new set of criteria for macrophage activation syndrome (MAS) complicating systemic juvenile idiopathic arthritis (sjia) is ongoing. The data-collection phase of the project has been recently completed.

\section{Objectives}

To describe the demographic, clinical, laboratory, and histopathologic features, therapeutic interventionsand outcome of 362 children with MAS collected in the study.

\section{Methods}

Patient data were collected retrospectively in a web-based database, developed and handled at the coordinating centre (Istituto G. Gaslini, Genoa, Italy).

\section{Results}

362 patients with sjia-associated MAS were entered in the study website by 95 investigators (78.2\% paediatric rheumatologists, $21.8 \%$ paediatric hemato-oncologists) from 33 countries. 208 patients (57.5\%) were females. Median age at onset of sjia was 5.3 years (IQR 2.7-10.1 years) and median disease duration at onset of MAS was 3.5 months (IQR 0.1-2.6 years); MAS occurred at onset of sjia in 77 patients (22.2\%). The most frequently observed clinical features were fever (96\%), liver enlargement (70\%) and spleen

${ }^{1}$ Istituto Giannina Gaslini, Genoa, Italy

Full list of author information is available at the end of the article enlargement (58\%); CNS involvement was reported in 122 patients $(35 \%)$ and haemorrhagic manifestations in 71 patients $(20 \%)$. The main laboratory abnormalities were: hyperferritinemia, increased D-dimer and liver enzymes, falling platelet count, hypertriglyceridemia and increased LDH. The most frequently reported trigger of MAS was sjia flare (53.8\%), followed by infections (37.8\%) and medication toxicity (4.3\%). Hyperferritinemia, increased liver enzymes, LDH, triglycerides and D-dimer and falling platelet count were the sole laboratory parameters that showed a percentage change greater than $50 \%$ between pre-MAS visit and onset of MAS. Hemophagocytosis was seen in $2 / 3$ of patients who underwent bone marrow aspirate. Therapeutic interventions included corticosteroids (97.7\%), cyclosporine (61.2\%), Iv Ig (36.3\%), biologic medications (15.2\%), etoposide (11.8\%), other immunosuppressants (7.1\%) and plasma exchange (4.1\%). ICU admission was required in $34.9 \%$ of patients; the mortality rate was $8.1 \%$

\section{Conclusion}

Fever and hepatosplenomegaly were the most frequently reported clinical features. Hyperferritinemia, increased liver enzymes, LDH, triglycerides and D-dimer and falling platelet count were the most frequently observed laboratory abnormalities. These laboratory parameters also showed the greatest change between pre-MAS visit and onset of MAS. Bone marrow aspirate exhibited hemophagocytosis in $2 / 3$ of instances. Corticosteroids and cyclosporine were the most frequently used medications. 


\section{Disclosure of interest}

None declared.

\section{Authors' details}

${ }^{1}$ Istituto Giannina Gaslini, Genoa, Italy. ${ }^{2}$ Childhood Cancer Research Unit, Dep. Of Women's and Children's Health, Karolinska Institutet, Stockholm, Sweden. ${ }^{3}$ International Investigator Consortium for MAS Diagnostic Criteria (IICMASDC), Riga, Latvia. ${ }^{4}$ IICMASDC, Buenos Aires, Argentina. ${ }^{5}$ IICMASDC, Madrid, Spain. ${ }^{6}$ ICMASDC, Jerusalem, Israel. ${ }^{7}$ IICMASDC, Strasbourg, France. ${ }^{8}$ IICMASDC, Muenster, Germany. ${ }^{9}$ IICMASDC, Messina, Italy. ${ }^{10} \| C M A S D C$, Cincinnati, USA. ${ }^{11}$ IICMASDC, Buffalo, USA. ${ }^{12}$ IICMASDC, Sankt Augustin, Germany. ${ }^{13}$ IICMASDC, Guangzhou, China. ${ }^{14}$ University of Alabama at Birmingham, Birmingham, USA.

Published: 5 December 2013

doi:10.1186/1546-0096-11-S2-P153

Cite this article as: Minoia et al:: PReS-FINAL-2141: Clinical features,

therapeutic interventions and outcome of 362 patients with

macrophage activation syndrome enrolled in a multinational survey.

Pediatric Rheumatology 2013 11(Suppl 2):P153.

Submit your next manuscript to BioMed Central and take full advantage of:

- Convenient online submission

- Thorough peer review

- No space constraints or color figure charges

- Immediate publication on acceptance

- Inclusion in PubMed, CAS, Scopus and Google Scholar

- Research which is freely available for redistribution

Submit your manuscript at www.biomedcentral.com/submit
Ciomed Central 